Molnár Zoltán ${ }^{1 \odot}$

\title{
Karitatív tevékenység a Nagy Háború idején Magyarországon, valamint Nagy-Britanniában és Franciaországban
}

\section{Charitable Activity during the Great War in Hungary as well as in Great Britain and France}

\begin{abstract}
Absztrakt
Tanulmányomban a nők karitatív munkában és a jótékonysági szervezetekben vállalt szerepét vizsgálom. Bemutatom az egyik legismertebb jótékonysági egyesület, az Auguszta-alap tevékenységét és jelentősebb akcióit. Emellett megvizsgálom a jószolgálat terén müködö egyik legkiemelkedőbb arisztokrata hölgy, Apponyi Franciska fóti aktivitását. A megannyi karitatív szervezet és személy kezdeményezései közül kiemelek néhány fontosnak tünőt. Végül két Antant-állam, Nagy-Britannia és Franciaország jelentösebb karitatív akciót mutatom be.
\end{abstract}

Kulcsszavak: Nagy Háború, nök, jótékonyság

\section{Abstract}

In my study, I examine the role of women in charitable activities and charity organisations. I present the activities and significant actions of one of the best-known charity associations, the Augusta Foundation. I will also examine the work of Franciska Apponyi from Fót, one of the most prominent aristocratic ladies in the field of good service. Of the actions of many charities and individuals, I will highlight some of the more significant 
ones. I present finally a major charitable action of two Entente States, Great Britain and France.

Keywords: Great War, women, charity

\section{A Nagy Háború és a hazai jótékonykodás}

Az 1914-1918 között zajló Nagy Háború küzdelmeinek elhúzódása miatt a kormányzat egyre inkább megkövetelte a nőktől is a háborús célok melletti kiállást, és az egyre növekvő ellátási hiány ellenére a kitartást. ${ }^{2}$ Mindezt a propaganda eszközeivel is igyekeztek megjeleníteni és népszerüsíteni. A tipikus nőideálnak az a hölgy volt tekinthető, aki elkötelezett honleányként, nem csupán részt vett a társadalmi gyüjtéseken, hanem személyes példamutatással is erősítette a nemzeti összefogást. Sebesülteket ápolt, erőn felül adakozott és hadikölcsönt jegyzett. Mindemellett a ruházati igényeket vissza kellett fogni, a konyhában pedig takarékoskodni.

Elmondható, hogy az arisztokrata hölgyek nagy számban kezdtek el jótékonykodni vagy vonultak be valamely kórház önkéntes ápolónői közé. A napi szinten jelen lévő halállal való közvetlen találkozás hatására sokan ábrándultak ki a háborúból. Az Osztrák-Magyar Monarchia már az első háborús év őszén olyan súlyos veszteségeket szenvedett, amelyeket a világégés végéig már nem is tudott pótolni. ${ }^{3} \mathrm{~A}$ gyász mellett jelentős anyagi nehézségekkel kellett szembesülniük azoknak a családoknak, amelyek a harctéren veszitették el hozzátartozójukat. Mindezért a jótékonysági akciók fókuszába a hadiözvegyek és a hadiárvák kerültek, továbbá jelentős figyelmet fordítottak a harctereken küzdő katonák ellátásának segítésére is. A háborús jótékonyság során számos karitatív szervezet végzett emberfeletti munkát. ${ }^{4}$

\subsection{Auguszta föhercegnő és az általa létrehozott alap}

A szervezet névadója, Auguszta Mária Lujza föhercegnő 1875-ben született Münchenben, Wittelsbach Lipót bajor herceg és Habsburg Gizella főhercegnő lányaként. Ferenc József unokája, József Ágost osztrák főherceg és magyar királyi herceg felesége, így a magyar nádori ág tagja volt. A világháború alatt Zita császárnéhoz hasonlóan ő is a Vöröskereszthez csatlakozott és segített a sebesültek ápolásában. Jelentős pénzadományokat ajánlott fel a segélyszervezeteknek. Számos jótékonysági egylet és akció fővédnöke volt. Férje kistapolcsányi birtokán élt a világégés évei alatt. A háborút követően is nagyon népszerủ maradt, számos karitatív szervezet munkáját segítette. József Ágost kezdettől fogva a fronton harcolt, így a föhercegnő osztozni tudott a lakosság sorsában. 1944-ben Amerikába emigráltak, majd a háborút követően Regensburgban

Balla Tibor: Szarajevó, Doberdó, Trianon. Magyarország az első világháborúban. Budapest, Scolar, 2019. 108.

A Monarchia fegyveres ereje 1914 őszén mintegy 600 ezer fös veszteséget (elhunytak, eltüntek, fogságba esettek, sebesültek, betegek) szenvedett. Vö. Balla Tibor: A militarista birodalom mítosza. Az osztrák-magyar haderő az első világháború előestéjén. Hadtörténelmi Közlemények, 127. (2014), 3. 643.

4 Bödők Gergely: „A munka frontján.” A nők változó társadalmi szerepe a Nagy Háború hátországában. In Glässer Norbert - Mód László (szerk.): A Nagy Háború hatása a mindennapok kultúrájának változására. Szeged, Néprajzi és Kulturális Antropológiai Tanszék, 2018. 409-410. 
telepedtek le, Auguszta főhercegnő sógornőjénél. 1964. június 25 -én ott hunyt el. ${ }^{5}$ A föhercegnő megnyerő modora s tettei miatt hamar közkedveltté vált. Rendkívül céltudatosan és folyamatosan lépett fel a háborús karitatív mozgalmak érdekében, közben pedig egyre több jómódú családot sikerült megnyernie a jótékonyság ügyének. Tevékenysége kiterjedt a kórházak felszerelésének fejlesztésére, a sebesültek pályaudvari és kórházi fogadására, a frontkatonák és családjaik segélyezésére, a harctéren küzdők segítésére. ${ }^{6}$ A Világháború képes krónikája így ír személyéről: „Míg férje a katona kötelességét teljesítette a déli határon, a hercegasszony éjt és napot egybevetve tett, fáradt, agitált a társadalmi mozgalmak érdekében. A kórházak fölszerelése, a sebesültek fogadása és ápolása, családok ellátása, katonák megvendégelése egyképpen beletartozott nemes gondoskodásának körébe és e napokban alig volt órája a napnak, hogy itt vagy ott, kórházban, pályaudvaron, vagy akár a kávéházban is feltünni ne láttuk volna fejedelmi alakját." ${ }^{17}$

1914. augusztus 1-jén egy fővárosi hölgybizottság kezdeményezésére, majd Auguszta föhercegnő újságokban megjelent felhívása után megindult a spontán pénzgyưjités a rászorulók megsegitésére. Az első támogató maga a főhercegnő volt, emellett ő vállalta a szervezet fövédnöki feladatait is. Az augusztus 6 -án megalakult szervezet legfontosabb célja volt hozzájárulni a háborús terhekhez, ehhez kérték a civil lakosság felajánlásait. Az alap fővédnöke maga a föhercegasszony volt, ügyvezető igazgatója pedig Lónyay Sándorné, leánykori nevén Becsky Ida, aki szépirodalmi munkáival vált ismertté. (1899-ben jelent meg a Jóslás a kézből című munkája, amely meghozta számára az elismertséget.) Az alap díszelnöke Csernoch János esztergomi érsek és hercegprímás, elnökei pedig Bárczy István (1906 és 1917 között Budapest polgármestere, 1917-1918-ban a főváros főpolgármestere), valamint Lánczy Leó (1881-től a Pesti Magyar Kereskedelmi Bank elnöke, a háború alatt a hadigazdálkodás megszervezésének egyik jelentős személyisége) voltak. A szervezet a hangsúlyt a segítségnyújtás gyorsaságára helyezte. Hamar nagy népszerüségre tett szert, az arisztokrácia tagjain kívül a középosztályból is sokan csatlakoztak hozzá. Képviselőik piros karszalagot viseltek, amelynek feliratán a „bánat és nyomor enyhítésére” felirat állt. Támogatták a frontkatonákat, a sebesülteket, a hadbavonultak családtagjait, a hajléktalanokat, az özvegyeket, az árvákat, a rokkantakat. A legkülönfélébb módon segítettek: készpénzzel, ruhával, élelmezéssel, fütőanyaggal és természetesen segélyezéssel. Az alap a sajtóban már az első évben komoly elismerésre tett szert. Tevékenysége mind szélesebb körre kiterjedt, ezért a szervezetnek osztályai jöttek létre különböző helyszíneken. Budapesten például a Kossuth Lajos utca 1. szám alatt alakították át a „Ferenciek bazárát". A felújított üzlethelyiségben kapható volt vasékszer, szerencsetü, árvácskajelvény, legyező és az elesett hőskatonák plakettje, Auguszta-naptár, gyűszü, valamint emlékpapír is. Emellett az 1914-es kraszniki csata után (ahol az 1. osztrák-magyar hadsereg legyőzte az orosz 4. hadsereget) elérhetők voltak az oroszoktól zsákmányolt ágyúkból készített hadi emlékérmék, győzelmi éremékszerek. ${ }^{8}$

Szijj Jolán - Ravasz István. (szerk.): Magyarország az első világháborúban. Budapest, Petit Real, 2000. 47.

Szoleczky Emese - Kreutzer Andrea: Az Auguszta Gyorssegély-alap tevékenységéről. A Hadtörténeti Múzeum Értesitője, (2011), 12. 17-18

A társadalom munkája. A világháború képes krónikája, (1914), 4. 125.

Szoleczky-Kreutzer (2011): i. m. 18-20. 


\subsubsection{Az Auguszta-alap jelentősebb kezdeményezései}

Ebben a részfejezetben az Auguszta-alap kezdeményezésével vagy részvételével létrejövő fontosabb jótékonysági akciókat mutatom be.

Az Auguszta-alap megalakulása után rögtön meghirdette az „aranyat vasért" mozgalmat. A begyüjtött aranytárgyakért „Pro Patria” feliratú vasgyürüt vagy vaskarkötőt, esetenként vasórát adtak cserébe. A Pesti Hírlap külön rovatban számolt be az eredményekről, kezdetben név szerint sorolták fel az adományozókat. Volt, aki pénzért váltotta meg a gyűrüt, így tett maga Ferenc József is, aki 5000 koronát fizetett érte, egyre inkább divatot is teremtve ezzel. 1915. január 14-től melltűt, nyakkendőtüt, óraláncot adtak cserébe. Emellett népszerüek voltak a karperecek, amelyeket a forradalomban elterjedt rablánckarkötőhöz hasonlítottak. A begyüjtött ékszerekből rendszeresen aukciókat rendeztek. Az egyik legismertebb az 1917. június 12-én megtartott drágakőárverés volt.

1914. augusztus 15-től Budapest összes éttermében és boltjában a számlához Tuszkai Márton plakáttervező által készitett kétfilléres segélybélyeget mellékeltek. Ez félmilliós nagyságú példányszámban készült el, amelyet az alapnak ingyen bocsátott rendelkezésére a Pester Lloyd és az Athenaeum Nyomda, valamint a Fővárosi Nyomda. Ezt váltotta fel később az Auguszta-garas. Ezt a különféle üzletekben és kávéházakban hozzászámították a számlákhoz.

Sok állástalan nőnek adott munkát az alap által életre keltett Auguszta-virág, amelyet 1914. október 10-től árultak 2 koronáért. A központi hatalmak zászlószíneiből összeállított ötszínű árvácska közepén „A" felirat volt olvasható. Ez is divattá vált, a szervezet céljaival egyetértők nagy számban viselték. 1914 októberétől éves rendszerességgel "Téli ruhát a szegényeknek" címen ruhákat gyűjtöttek. „Halottak az élőkért” címmel segítettek a halottak napi megemlékezésekben. Auguszta-szalagot tüztek a koszorúkra és a kegyelet adója néven segítették a rászorulókat. 1914 végére elkészült az Augusztaplakett a hösök emlékére. A feliratán Horatius idézete volt olvasható: Dulce et decorum est pro patria mori („édes és dicső a hazáért meghalni”). A Hadsegélyező Hivatallal közös volt az akció, és hamarosan a plakettek viselése is divattá vált.

Jelentős kezdeményezés volt a német mintára 1914. november 2-tól évente folyamatosan megrendezésre kerülő Katonák karácsonya. Ennek célja az volt, hogy a frontra a Hadsegélyező Hivatal segítségével három-négyfajta láda kerüljön, amelyeknek fedelét fenyőgally, valamint a német és az osztrák uralkodó képe díszítette s nemzeti színű szalaggal kötötték át. Mindegyik láda tartalmazott mézeskalácsot, cigarettát, szivart, kétszersültet, ceruzát, tábori levelezőlapot, szappant és csokoládét. Az elesett katonák árvái és a sebesültek hozzátartozói - mintegy 1500 család - az alap központi helyén felállított karácsonyfa alatt vették át ajándékukat. A ruházati ajándékokat például a kereskedők szövetadományaiból azok feleségei varrták. 1915. január 9-én a középosztály segítése céljából került sor az Auguszta-tombola megszervezésére, amely festményekből, szobrokból rendezett tárgynyeremény-játék volt. Auguszta lánya, Zsófia hercegnő szervezésében rendezték meg a babakiállítást (maga Zsófia is felajánlotta játékait), továbbá tucatnyi mesedélutánt és hangversenyt is tartottak.

A jótékonysághoz csatlakozott a Zeneakadémia is. Az 1914-1915-ös évadban például világhírü zenészek léptek fel. A bevételböl többek között a Vöröskereszt és az orosz betörésektől szenvedő északi vármegyék részesültek. A Hadi emlékérem a kraszniki 
ütközetben zsákmányolt orosz ágyúk fémjéből készült, ezt az uralkodó adományozta a szervezetnek. Bronz változatai 10, illetve 5, a vasból készültek 2 , illetve 1 koronáért voltak kaphatók. Aranyba és ezüstbe foglalt „háborús ékszerek" is készültek belöle, amelyeket Murányi Gyula szobrász tervezett.

Az 1915 májusában megrendezett „Füsttelen nap” is jól illett az alap tevékenységébe. A város forgalmas helyein (a Margitsziget, a Városliget, a Korzó, továbbá a kávéházak és a trafikok) különböző kitűzőket árultak, eltérő árakon, hogy minél többen vehessék meg azokat. A megvásárolt jelvények viselője egy napi dohányköltségét váltotta meg. A hadirokkantak támogatására szánták. A tarka „füsttelen jelvények" ára 20 fillértől 10 koronáig terjedt. Az akcióban segítettek a házmesterek, akik „füstadót" vetettek ki. A „Füsttelen napot” egyébként országszerte megtartották: a budapesti rendezvényhez aznap még 75 település csatlakozott, majd a többi helység július és augusztus hónap folyamán. Ennek a kezdeményezésnek a bevételéből hozták létre az Auguszta-rokkantalapot. A középfokú végzettséggel rendelkező, családtalan, teljes rokkantaknak 100 ágyas szanatóriumot akartak létrehozni a rokkantalap pénzéből. A szakirodalomban csak a Nemzet Házaként emlegetett intézményt azonban forráshiány miatt végül nem sikerült megvalósítani.

1915. május 7-én indult első útjára 109 rokkant katonával a fedélzetén az Augusztahajó, amelyet a Magyar Folyam és Tengerhajózási Rt. bocsátott rendelkezésre jótékonysági célra az alap részére. A hajó naponta háromszor, kétórás sétautat tett a Dunán az Eötvös-téri kikötőből indulva. A budapesti hadikórházak sebesült katonáit hétfőnként kirándulni vitték, délelőtt 150, délután pedig 250 főt tudtak a hajón utaztatni. A hét többi napján a hajót a budapesti közönség vehette igénybe 3 koronáért, mindez tartalmazta az uzsonnát is. Szombatonként még hangverseny és kabaré is várta az érdeklődőket. Vasárnap délelőtt pedig a gyerekeknek biztosítottak tartalmas programot.

Német mintára a segélyszervezet 1916 elején a hadibiztosítás bevezetését kezdeményezte. A biztosításokat előbb a Phőnix Biztosító Rt. végezte, majd a Rokkantügyi Hivatal előírásait teljesítve az alap létrehozta az Auguszta Általános Biztosító Rt-t. A Hadibiztosítási Osztály vállalta a biztosítások propagálását és annak felügyeletét, cserébe a nyereségből részesedtek. A fronton harcoló katonák családtagjai, továbbá a települések egyaránt megköthették a harcoló nevére, haláleset, rokkantság esetére, havi díjfizetéssel. 1917 áprilisáig a statisztikai adatok szerint közel 100 ezer család vált biztosítottá.

Fontos fővárosi látványosság volt a Pasaréti Lövészárok, amely tulajdonképpen egy háborús skanzenként müködött. 1915. augusztus 11-én nyitotta meg kapuit. A keleti fronton, Tomaszów Lubelski közelében 1915-ben az oroszok ellen vívott harctér lövészárok-rendszeréhez hasonlót készítettek el Pasaréten. Külön figyeltek a minél könnyebb megközelíthetőségre, a Hűvösvölgyi villamos, nagyjából a mai Nagyajtai utca megállóhelynél, a Lövészárok bejáratánál külön megállóhelyet kapott.

Mindennap 10-22 óráig tartott nyitva, délelőtt a középiskolások végeztek benne harcászati gyakorlatokat, délután látogathatta a közönség. Katonazene, hadi pékmúhely, gulyáságyú is várta az érdeklődőket. Csütörtök este tűzijátékot és fényszóró gyakorlatokat tartottak, bemutatták a háborús újdonságok - mint például a világítóbombák, jelzőrakéták, gépfegyverek, periszkópok - szerepét és használatát. Villanylámpákkal világították meg a területet. A fegyverek mellett hidak, tábori kórházi berendezés, 
valamint nyolc sátorban elhelyezett alkalmi hadi felszerelési kiállítás is hozzátartozott. Teljes bevételét a Nemzet Háza felállítására fordították, azonban ismeretlen időpontban, még a háború vége előtt felszámolták. ${ }^{9}$

Az adakozás előremozdítását segítette a Nemzeti Áldozatkészség szobra, amely Sidló Ferenc szobrászmúvész alkotása volt. Korábbi bécsi kezdeményezés mintájára a magyar kormány 1915 elején döntött arról, hogy a Hadsegélyező Hivatal állítson fel egy fából készült, Mátyás-kori lovas szobrot. 1915. szeptember 12-én Tisza István miniszterelnök Csernoch János hercegprímás jelenlétében avatta fel az Anker Biztosító Társaság székháza előtt, a Deák-téren. A beszédet az esztergomi érsek tartotta. Két korona értékében névvel ellátott fémpikkelyeket lehetett vásárolni és azokat a szoborra szegelni. (1919. május 1-jén a kommunisták pavilont emeltek a szobor elé, amelyet Szabó Ervin nagyméretü gipsz portréja díszített. 1924 novemberében a szobrot a Ludovikára szállították, a II. világháborút követően szétbontották, darabjai a Kiscelli Múzeumba, illetve a Hadtörténeti Múzeum raktárába kerültek.) Kicsinyített szobrok is készültek, a talapzat két oldalán a Hadsegélyzö Hivatal és Az Auguszta-alap felirat volt olvasható. Hasonló szobrok felállítására került sor Székesfehérváron, Nagyváradon, Kolozsváron és Szegeden is..$^{10}$ A szoborállítási mozgalom tehát 1915. március 6 -án Bécsből indult, majd a Monarchia és a Német Császárság teljes területén emeltek hasonló alkotásokat. Mi több, világszerte elterjedtek, Európa más országain túl, még az Egyesült Államokban és Argentínában is születtek hasonló kezdeményezések.11

Kiemelkedő szerepe volt a 41. számú, 264 méter hosszú Auguszta-mentővonatnak, amely 1915. február 18-tól a Monarchia fennállásának végéig szállította a sérült katonákat. A Budapesti Önkéntes Mentőegylet számára Alexander Krobatin közös hadügyminiszter bocsátotta rendelkezésre. A mentőegylet fővédnöke József Ágost főherceg volt. Kezdetben a harcterekhez közeli báziskórházakból a fővárosba szállították rajta a sérülteket. Később a frontvonalak között is közlekedett, még a Német Császárság területére is eljutott. Akár 10-15 pótkocsit is hozzá lehetett csatolni, egyszerre 800 sérültet szállíthatott, elsősegélyt nyújtott és műszaki mentést is tudott végezni. Személyzetéhez két egészségügyi tiszt, valamint 34 fö tartozott. Egészségügyi és műszaki mentőszemélyzetre tagolódott. A háború időszaka alatt összesen 69763 utast szállított. A magyar mentőtörténelem egyik kiemelkedő alakja és a mentőszolgálat második vezetője, Kovách Aladár megvalósította a műszaki mentés, a betegszállítás és az elsősegély-nyújtás együttes alkalmazását, elsőként a világon.12

\subsection{Gróf Apponyi Franciska fóti jószolgálata}

Apponyi Franciska 1879-ben született Bécsben, a nagy múltú arisztokrata család sarjaként. Már 18 évesen férjhez ment a szintén előkelő családból származó Károlyi

\footnotetext{
Szoleczky-Kreutzer (2011): i. m. 20-28.

Szijj-Ravasz (2000): i. m. 494.

11 Vizi László Tamás: „Felállítottuk ezen emlékművet...” - A nemzeti áldozatkészség székesfehérvári szobra a terv megszületésétől, az 1915-ös megvalósításig. In Szakály Sándor (szerk.): Székesfehérvár, Magyarország és a Nagy Háború. Budapest, L'Harmattan, 2015. 78.

12 Debrődi Gábor: Vasúti mentés az első világháborúban. A 41. számú Auguszta mentővonat története.
} 
Lászlóhoz, akinek fóti kastélyába költöztek a világháborút megelőzően. A Nagy Háború gyökeresen felforgatta a társadalmi viszonyokat. Mivel nagyon sok családban a harcterekre kerülő férfiak voltak a családfenntartók és a keresők, az asszonyok tömegével maradtak egyedül és bevétel nélkül. Mindezért sokan munkavállalásra kényszerültek, azonban gondot jelentett a kisgyermekek elhelyezése. Apponyi Franciska hozta létre az első ingyenes orvosi ellátást és gyógyszereket biztosító anya- és csecsemővédő intézményt Fóton, illetve Tanácsadó Irodát is alapított. A Tanácsadó Iroda előbb a fóti kastélyban, majd annak parkjában, különálló épületben müködött 1915 januárjától. Segélyezték a frontszolgálatosok családtagjait, élelemmel, ruházattal igyekeztek ellátni a katonákat. Az intézmény legfőbb feladata az eltűnt harcosok felkutatása, a kérvények és levelek megírásában történő segítségnyújtás volt. Egy 60 ágyasra tervezett csecsemőotthont is létesítettek. Az intézménybe a munkába induló anyák féléves kortól hároméves korig bevihették gyermekeiket, akik ott teljes körü ellátásban részesültek. Havonta kétszer, vasárnap délutánonként a fiatal anyáknak előadásokat tartottak. Szakképzett ápolónők foglalkoztak a gyermekekkel.

Az újpesti kórház nem kapott közvetlen betegátvételre engedélyt, mivel az 300 betegágyhoz volt kötve, míg az intézményben csak 260 állt rendelkezésre. A grófnő felkereste az összes magyar hatóságot, és 1916 decemberében Bécsben, a hadügyminiszternél sikerült elérnie, hogy a távolabbi kórházakban ápolt betegeket átszállítsák Újpestre. Fóton megalapította a családlátogatók intézményét is. Hetente látogattak meg tíz-tíz szegény sorsú családot, amelyeknek rászorultság alapján javasolták a természetbeni segély mértékét. Fótot 17 körzetre osztották fel, mindegyik élén egy-egy családlátogató asszony állt. Feladatuk környezettanulmányok készítése, továbbá a megsegítés módjára történő javaslattétel volt. A munkaképteleneket, ha nem rendelkeztek az eltartásukhoz szükséges hozzátartozóval, a település szegényházába vették fel. A grófnő a Nagy-tó alatti területet felszántatta és 400 négyszögöl nagyságú telkeket osztottak ki 76 rászoruló családnak. Még a vetőmagot is ők adták. A népkonyha számára a burgonyatermés felét be kellett szolgáltatniuk, ahol napi 100 adag ételt osztottak szét. A többi termés és vetőmag azonban az új tulajdonosoknál maradt. Emellett még varrodát is alapított, amelynek célja az volt, hogy a nők maguk is el tudják végezni a ruhák varrását.13

\subsection{A magyar karitatív szervezetek áldozatos munkája}

A háború alatt óriási mértékben csökkent a születések száma, ezért rendkívül lényegessé vált a csecsemö- és anyavédelem. Rendkívül fontos szervezet volt a Rudolf trónörökös özvegye nevét viselö Stefánia-szövetség, amelyet gróf Apponyi Albert vezetett. Az ismeretek terjesztésére tanfolyamokat is szerveztek. 1916-ban a kormányzat anyagilag is támogatta a szervezet tanfolyamait. (A 135.840/1917. számú belügyminiszteri rendelet rendelkezett a szövetség támogatásáról.) Felemelték a gyermekágyi

\footnotetext{
13 Völgyesi Zoltán: Harctértől a hátországig. Az első világháború gazdasági és társadalmi hatásai Magyarországon a levéltári források tükrében. Budapest, L'Harmattan, 2016. 189-200.
} 
segély összegét és azt a korábbi 6-ról 8 hétre terjesztették ki. Bevezették továbbá a szoptatási segélyeket is. ${ }^{14}$

A szövetség szervezése 1914 szeptemberében kezdődött meg, 1915. június 13-án tartották alakuló ülését. Ma is ezt az időpontot tartjuk számon a védőnői szolgálat létrejöttének időpontjaként. Az alapszabály tervezetét és a szervezet programját dr. Madzsar József orvos, szociálpolitikus készítette el. A szövetség együttmüködött a Munkásbiztosító Pénztárral is. A Budapesten 1917 óta müködő Népjóléti Központ is csatlakozott a kezdeményezéshez. A budapesti üzemek és villamos társaságok figyelmét arra hívták fel, hogy alakítsanak ki szoptatós szobákat, ahol a munkásnők napközben elhelyezhetik gyermekeiket. ${ }^{15}$

A Magyarországi Nőegyesület Szövetsége Tanácsának döntéséröl a Pesti Hírlap is beszámolt. Nevezetesen arról, hogy a tanítók számára a Vöröskereszt segédápolói tanfolyamot szervezzen legalább a fővárosban, s kérték a nők abban való részvételét. Azt is fontosnak tartották, hogy a képzettek és kellő szabadidővel rendelkezők vállaljanak munkát: lehetőség szerint a lakóhelyükön, de segédkezzenek a hadseregnél, illetve lássanak el ápolási feladatokat a kórházakban is. Az egyesület tagszervezeteit munkaközvetítő irodák felállítására ösztönözte. Magyar Nők Országos Segélyalapja néven gyüjtést rendeztek a szegények számára. A tehetősebb családokat arra kérték, hogy legalább délben biztosítsanak étkezési lehetőséget a behívott katonák gyermekeinek. A nőegyesület felhívta tagjai figyelmét arra is, a népkonyhák megnyitása után mennyire fontos ebédjegyek osztásával támogatni a kereset nélkül maradt rászorulókat. A dolgozó anyák gyermekeit lehetőség szerint napközibe gyűjtsék, a tehetősebb lánygyermekeket pedig ösztönözzék a szegény gyermekekkel való foglalkozásra. Valamint azt is szerették volna elérni, hogy gyújtsenek fehérnemüt, ruhákat a Vöröskereszt számára. ${ }^{16}$

A Magyar Úrinők Egyesülete Szentendrén a „Magános Úrinők Otthonában” berendezett három Auguszta- és Erzsébet-szobát felajánlotta a Honvédelmi Minisztérium részére. Elsősorban az idősebb nők számára biztosították a szolgáltatást ingyenesen, azoknak, akik csupán kegydíjban részesültek. ${ }^{17}$ Balatonszabadiban a Zsófia Országos Gyermekszanatórium Egyesület 225 ágyas szálláshelyet létesített az elesett katonák árvái számára. Az avatásra a Déli Vasút különvonatot indított. A beteg gyermekek ott korszerü körülmények között gyógyulhattak. ${ }^{18}$

Jelentős szerepet vállaltak a jótékonyságban a különféle egyházi szervezetek is. A Katolikus Karitasz meleg ruhával, élelemmel látta el a katonákat. Gyermekeiknek elhelyezést biztosított napközikben, feleségeiket, özvegyeiket munkához segítette. Élelmiszerrel látta el a munkanélküli nőket. ${ }^{19}$ Szintén kiemelkedő szervezet volt a Magyar Nők Korona Alapja, az egyik legelső jótékonysági kezdeményezés a háború kitörését követően. Tagsági díja 1 korona volt, a hozzájuk befolyt adományokat a hadiözvegyeknek és -árváknak ajánlották fel. Együttmüködtek Budapesten a Hadsegélyző Hivatallal,

14 Völgyesi (2016): i. m. 189.

15 Zalai Katalin: Háborús nöügyek. In Kaba Eszter (szerk.): Háborús mindennapok - mindennapok háborúja. Budapest, Napvilág, 2017. 241-242.

16 A magyar nök akciója. Pesti Hírlap, (1914), 181. 7.

7 Otthon az elesett katonák hozzátartozóinak. Pesti Hírlap, (1914), 296. 13.

18 A balatonszabadi gyermekszanatórium felavatása. Az Est, (1917), 214. 7.

19 Szijj-Ravasz (2000): i. m. 335. 
vidéken a Hadsegélyző Hölgybizottságokkal, amelyek hivatalos emlékszelvényeket állítottak ki az adományokról. ${ }^{20}$

Andrássy Klára grófnő felhívására a Gyermekszívek Karácsonya elnevezésű jótékonysági esemény fővédnökségét Zsófia föhercegnő vállalta el. Az Uránia Országos Nővédő Egyesület hatalmas összeggel támogatta az akciót. 1000 szegény gyermeket juttatott ruhához, s mintegy 3000-4000 gyermeket könyvhöz, valamint játékhoz. Azonkívül Rónay Jenő császári és királyi tengerész-hadbíró kérésére a tengerészek számára könyveket is küldtek. ${ }^{21}$

\section{Háborús karitatív tevékenység Nagy-Britanniában és Franciaországban}

A nyugat-európai államokban is - hasonlóan Magyarországhoz - a nők hoztak létre civil szervezeteket. A katonák ellátásán túl alapítottak egyesületeket a menekültek és a sebesültek gondozására is. A worcesteri egyetemen például leginkább belga menekülteket láttak el. Nők töltötték be az ápolónői, nevelő és gondozó szerepköröket is. A királyi család alkalmazott például szakácsnőket vagy éppen gyógyfükereskedőket is. Anglia gyógyszerészeti ipari annyira visszaesett, hogy a Monarchiából importáltak gyógynövényeket. A worcesteri egyetem a háború alatt kórházként és menekültotthonként müködött. ${ }^{22}$

A háború kitörése után Angliában az arisztokrácia és a jobb módú emberek jelentkeztek önkéntesnek a Háborús Hivatal szolgálatába. A háború idején közel 18 ezer karitatív szervezetet hoztak létre, tevékenységük kiterjedt a ruházat, az élelem, a könyvek szállítására a hadseregnek, az orvosi szolgáltatásokra, a hadifoglyoknak nyújtott segítségre, a háború utáni megemlékezésekre. Edward walesi herceg vezetésével Nemzeti Segélyalapot hoztak létre. Egy hét alatt a befolyt adományok összege elérte az egymillió fontot. A belga menekültek segítésére a Millicent Fawcett által vezetett Női Szavazati Társaságok Országos Szövetsége ${ }^{23} 150$ tolmácsot biztosított. 265 ezer menekült érkezett az első tíz hónapban a szigetországba. Létrehozták a jótékonysági szervezetek helyi hálózatát is. Az újságokban folyamatosan felhívások jelentek meg, gyűjtéseket szerveztek. Az egyik legnagyobb jótékonysági szervezet, a Füst a Sebesült Katonák és a Tengerészek Társadalma Számára ${ }^{24}$ volt. Fag Day elnevezésü rendezvényeket tartottak, ahol több mint egymilliárd cigarettát osztottak ki a sebesült férfiaknak. A királyi család tagjai megjelenésükkel, védnökségükkel támogatták a rendezvényeket. A háború elején számos nő veszítette el állását, leginkább a textiliparban, amikor bezártak az exportpiacok. A Háborús Sürgősségi Dolgozók Nemzeti Bizottsága, aminek tagjai voltak a szakszervezetek vezetői is, segített a helyzetükön. Létrehozták továbbá a Queen's Work for Women Fundot. Az iskolákban úgynevezett Tojás Napokat tartottak, a sebesülteknek gyüjtötték őket a gyerekek. Kiemelkedő eseménynek

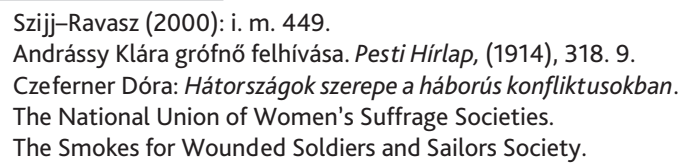


számítottak az 1914 szeptemberétől indult, úgynevezett Zászló Napok, amelyeken a háborús özvegyeknek, katonáknak, hadifoglyoknak gyűjtöttek. A támogatókat arra buzdították, hogy zászlótúket vásároljanak, amelyeket nemzeti ruhát viselő nők értékesítettek. 1917 decemberében India-napot tartottak. A Mezopotámiában meg Indiában szolgáló katonáknak és azok családtagjainak gyüjtöttek. A háború végére az egy napi adomány értéke elérte a 25 millió fontot, amely ma 1,75 milliárd fontnak felel meg. A Times újság által létrehozott Times Alapítvány a brit Vöröskereszt és a Szent János Mentőszolgálat égisze alatt működő közös háborús bizottságnak gyűjtött. Elsie Inglis, az egyik első diplomás női orvos volt Angliában. Megszervezte a Skót Női Kórházak Külügyi Szolgálatát, ${ }^{25}$ helyi kórházakat hozott létre a szövetséges erők számára. A skót női kórházak 14 orvosi egységet hoztak létre Szerbiában, Franciaországban, Korzikán, Szalonikiben, Romániában, Oroszországban és Máltán. Inglis számos kórházat vezetett, védőoltásokkal küzdött a tífusz és a kolera ellen. Egészen a rákos betegség által okozott haláláig dolgozott. 1917-ben hunyt el, 53 évesen. ${ }^{26}$

A franciák megalapították az Apa Nélkül Maradt Gyermekek Jótékonysági Szervezetét. ${ }^{27}$ Arra kérték az amerikaiakat, hogy legalább tíz napra fogadják be a gyermekeket. Úgy vélték, hogy az apjuk vallása szerint kell nevelni őket, az anyjukkal és a testvéreikkel együtt, ha ez lehetséges. Családtag híján képzett gyámot neveztek ki. Országszerte megalakultak a szervezet bizottságai.

Franciaországban az adománygyüjtés a háború kezdetétől folyt, egészen addig, amíg az USA belépett a világháborúba. A Testvériség Szervezete a Francia Gyerekekért ${ }^{28}$ 1917 novemberében újraszervezésre került, Joffre tábornok lett az elnöke. 1918. május 21-én 58 árvákat támogató intézmény működött alárendeltségében, illetve az Egyesült Államokban 180 társult bizottsága jött létre. Kuponokat küldtek a rászoruló özvegyeknek. Fontos szervezet volt az 1914. augusztus 2-án megalakult Árvák Háborús Egyesülete is. ${ }^{29}$ Jótékonysági Zászlós napokat tartottak például 1916. július 14-én (a Bastille Napján vagy Párizs Napja). ${ }^{30}$

$A z$ I. világháború idején északkelet-Franciaországban 350 önkéntes amerikai nő tevékenykedett. Közülük is kiemelkedett Anne Morgan, J. P. Morgan lánya, aki megalapította az Amerikai Bizottságot az Elpusztított Franciaországért. ${ }^{31}$ Az amerikai nők Château de Blérancourt kastélyában éltek, Ford teherautókon szállították őket. Irányították a mezőgazdasági termelést és az épületek helyreállítását. Életre hívták a vendég ápolónők hálózatát, könyvtárakat, szociális központokat, óvodákat hoztak létre, olyan közéleti eseményeket szerveztek, amelyek erősítették a társadalmi kapcsolatokat. Az I. világháború után hozta létre Anne Morgan a Francia-Amerikai Múzeumot, amely manapság az Egyesült Államok és Franciaország barátságának és együttmüködésének előmozdítására szolgál.

Anne 1914 nyarát Franciaországban töltötte. A szörnyű Marne-i csatatéren történt látogatása után úgy döntött, hogy a szövetséges ügynek szenteli tevékenységét. 1917-ben

\footnotetext{
Scottish Women's Hospitals for Foreign Service Committee.

Carol Harris: 1914-1918. How charities helped to win WW1.

Fatherless Children of France.

Fraternal League for the Children of France. Eredetileg 1896-ban alakult meg.

The Association of Orphans of War.

Madame Guérin: Chapter 4: Lecturing and WW1 Charity Fundraising in USA.

American Committee for Devastated France.
} 
hozta létre a már említett Amerikai Bizottságot az Elpusztított Franciaországért, New York-i irodákkal. Hetente jelentetett meg kiadványt Két zászló alatt címmel, és fényképeket készített a szervezet tevékenységének bemutatására. A bizottság 1918 márciusáig 800 családnak segített önellátóvá válni, továbbá anyagilag és képzésekkel is támogatta a rászorulókat. ${ }^{32}$

A külügyminisztérium fötitkárának (Jules Cambon) védnöksége alatt állt a Marguerite De Lens által 1915 januárjában létrehozott a „Katonák családja"33 elnevezésű jótékonysági szervezet, amelynek célja az volt, hogy erkölcsi támogatást nyújtson azoknak a katonáknak, akik Franciaország északi és keleti részéről, az idegen fennhatóság alá került területekről származtak, s nem tudtak levelet kapni családjuktól. Összesen 25 ezer katona vett részt a programban.

Még több hasonló, a katonák és családtagjaik támogatását előtérbe helyező szervezet is létezett, mint például az 1915-ben az Alexandre Millerand hadügyminiszter támogatásával létrejövő „Katonáim”. 34 1915-ben hivatalos intézménnyé vált a háborús levelezőtársak szervezete, a „Keresztanyák”,"35 amelynek keretében a magányos katonáknak lehetőségük volt levelezni női levelezőtársakkal, sőt anyagi támogatást is nyújtottak a katonáknak. Később azonban felmerült a kémkedés vádja a szervezettel szemben. Az intézmény népesség körében való sikerének és ellentmondásos értelmezésének bizonyítéka megtalálható olyan regényekben, színdarabokban és dalokban, amelyek vagy dicsőítik a női tollbarátokat és katonákat, akiknek írtak, hangsúlyozva az érintett nők hazafias aspektusát és jóságát, vagy pedig azon gúnyolódnak, hogy a levélírási gyakorlatok végső soron az udvarlásra és az álnokságra irányultak, ami távol állt a rendszer alkotói által elképzeltektől. A női levélírók és férfi társaik olyan figurákká váltak, akiket az irodalom vagy az Union Sacrée emblémájaként, vagy a nemzet erkölcstelenségének és elfajulásának képviselőiként ábrázol. Minden gyanakvás ellenére azonban 1939-ben újjáéledt a Nagy Háború idején létrejött tollbarátok intézménye. ${ }^{36}$

\section{3. Összegzés}

Összefoglalva elmondható, hogy az első világégés folyamán a karitatív szervezetek, az arisztokráciához, valamint a középosztályhoz tartozó hölgyek erőn felül támogatták a frontkatonákat és családtagjaikat, a társadalom esendőbb tagjait, kiegészítve az állami intézmények segélyezését. Jelentős munkát végeztek a férfiak által alapított jótékonysági szervezetekben is. A mai kor embere számára is példaértékű jószolgálati munkát teljesítettek. Mindezt az egyre fokozódó háborús áruhiány és a növekvő veszteségek közepette tették. Úgy vélem, hogy a Nagy Háború harcai és főbb eseményei mellett e szervezetek és emberek munkájáról is méltó módon kell megemlékezni.

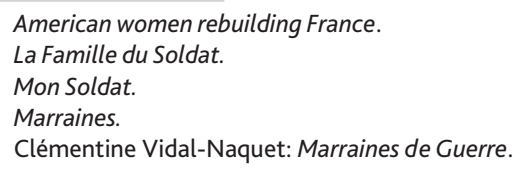




\section{Felhasznált irodalom}

A balatonszabadi gyermekszanatórium felavatása. Az Est, (1917), 214. 7.

A magyar nők akciója. Pesti Hírlap, (1914), 181. 7.

American women rebuilding France. Online: www.theworldwar.org/explore/exhibitions/ past-exhibitions/american-women-rebuilding-france

Andrássy Klára grófnő felhívása. Pesti Hírlap, (1914), 318. 9.

A társadalom munkája. A világháború képes krónikája, (1914), 4. 125.

Balla Tibor: A militarista birodalom mítosza. Az osztrák-magyar haderő az első világháború előestéjén. Hadtörténelmi Közlemények, 127. (2014), 3. 628-645.

Balla Tibor: Szarajevó, Doberdó, Trianon. Magyarország az első világháborúban. Budapest, Scolar, 2019.

Bödők Gergely: „A munka frontján.” A nők változó társadalmi szerepe a Nagy Háború hátországában. In Glässer Norbert - Mód László (szerk.): A Nagy Háború hatása a mindennapok kultúrájának változására. Szeged, Néprajzi és Kulturális Antropológiai Tanszék, 2018. 409-419.

Czeferner Dóra: Hátországok szerepe a háborús konfliktusokban. Online: http://ujkor. hu/content/hatorszagok-szerepe-a-haborus-konfliktusokban

Debrődi Gábor: Vasúti mentés az első világháborúban. A 41. számú Auguszta mentővonat története. Online: www.mentomuzeum.hu/hun/images/letoltesek/debrodi_auguszta_mentovonat.pdf

Harris, Carol: 1914-1918. How charities helped to win WW1. Online: www.thirdsector. co.uk/1914-1918-charities-helped-win-ww1/volunteering/article/1299786

Madame Guérin: Chapter 4. Lecturing and WW1 Charity Fundraising in USA. Online: https:// poppyladymadameguerin.wordpress.com/chapter-4-lecturing-and-ww1-charity-fundraising-in-usa/

Otthon az elesett katonák hozzátartozóinak. Pesti Hírlap, (1914), 296. 13.

Szijj Jolán - Ravasz István. (szerk.) Magyarország az első világháborúban. Budapest, Petit Real, 2000.

Szoleczky Emese - Kreutzer Andrea: Az Auguszta Gyorssegély-alap tevékenységéről. A Hadtörténeti Múzeum Értesítöje, (2011), 12. 17-27.

Vidal-Naquet, Clémentine: Marraines de Guerre. Online: https://encyclopedia.1914-1918-online.net/article/marraines_de_guerre

Vizi László Tamás: „Felállítottuk ezen emlékművet...” - A nemzeti áldozatkészség székesfehérvári szobra a terv megszületésétől az 1915-ös megvalósításig. In Szakály Sándor (szerk.): Székesfehérvár, Magyarország és a Nagy Háború. Budapest, L'Harmattan, 2015. 78-107.

Völgyesi Zoltán: Harctértől a hátországig. Az első világháború gazdasági és társadalmi hatásai Magyarországon a levéltári források tükrében. Budapest, L'Harmattan, 2016.

Zalai Katalin: Háborús nőügyek. In Kaba Eszter (szerk.): Háborús mindennapok - mindennapok háborúja. Budapest, Napvilág, 2017. 225-251. 